\title{
TEOLOGI PAULUS DALAM SURAT TITUS
}

Philipus Pada Sulistya*

Email:pada_sulistya@yahoo.com

Sekolah Tinggi Theologi Injili Indonesia, Yogyakarta

\begin{abstract}
This paper aims to present the theology of Paul in Titus. Although this letter addressed to Titus, but the contents of this letter should be heard by the whole church and not just the leaders. At the center of the theology of pastoral letters there is a need to defend the faith against heretics who is starting to affect church. While investigating this letter, we would see all practical purposes when discussing the problems facing the existence of churches. However, the amazing thing is is that the range of theological truth that underlies such practical advice. Therefore, understanding the various theological concepts presented in this book help us appreciate the truth of which Paul speaks to uphold a healthy church.
\end{abstract}

Key Words: Teachings, Pastoral, Sound Doctrine, Heresy.

\section{Pendahuluan}

Setiap orang adalah teolog, entah bagaimana keadaannya (teolog yang baik atau sebaliknya) ${ }^{1}$. Seorang teolog yang sejati selalu berpikir dan berbicara tentang Allah. Sebab jika seorang berbicara tentang teologi pastilah ia akan menyinggung perihal Allah. Kata teologia sendiri dimengerti dari asal kata theos yang berarti Allah dan kata logos yang berarti perkataan. Seperti yang didefinisikan secara singkat oleh Georffry W. Bromiley bahwa "teologi" adalah segala sesuatu yang dipikirkan dan dikatakan tentang Allah. ${ }^{2}$ Shorter Oxford Dictionary mendifinisikan teologi sebagai "studi atau ilmu mengenai Allah, hakekat dan sifat-sifatNya, serta hubunganNya dengan manusia semesta

*PHILIPUS PADA SULISTYA, M.TH (STTII Yogyakarta) adalah seorang dosen Perjanjian Lama di Sekolah Tinggi Theologia Injili Indonesia, Yogyakarta.

${ }^{1}$ Charles C Ryrie, Teologi Dasar I (Yogyakarta: Yayasan Andi, 1991), 9.

${ }^{2}$ Everett F. Harrison, Geoffey W. Bromily dan Carl F.H. Henry (ed), Bakser's Dictionary of Theology (Grand Rapids, 1960), 518. 
alam." Sedangkan Morris menyatakan bahwa teologi mencerminkan kiat orang Kristen untuk menyajikan secara teratur pemahaman mengenai Allah dan penyataanNya di dalam Kristus, dan tentang makna semuanya itu bagi para penyembahNya. ${ }^{3}$

Rasul Paulus adalah seorang teolog yang sangat berbakat dan diakui kewibawaannya. Tulisan-tulisan Paulus dalam bentuk surat-surat yang menjadi kanon Alkitab merupakan ulasan teologi yang sangat berharga dan bermanfaat bagi gereja. Teologi Paulus sangat padat dan mendalam dan sudah terbentuk sejak dini. ${ }^{4}$ Tulisannya merupakan bukti yang kuat bahwa pandangan kristiani yang pokok sudah terbentuk secara kokoh sebelum pertengahan abad pertama, kurang dari 20 tahun sejak Yesus mati.

Semua surat Paulus berasal dari suatu periode waktu yang termasuk singkat yakni menjelang akhir hidupnya. Namun ini bukan berarti ada perkembangan dalam pemikiran rasul Paulus yang dipaparkan dalam suratsuratnya. Pandangan teologisnya pasti sudah terbentuk sebelum ia menulis surat-suratnya, karena Paulus sudah menjadi Kristen dan seorang pemberita Injil selama 17 tahun atau lebih sebelum ia menulis surat yang pertama dari antara surat-suratnya yang dimiliki gereja. Perbedaan-perbedaan dalam surat Paulus adalah karena perbedaan lingkungan sang rasul dan perbedaan situasi yang melahirkan surat-surat tersebut bukan karena perkembangan cara berpikir Paulus.

Ada perdebatan mengenai tulisan-tulisan manakah yang berasal dari Paulus. Banyak ahli berpendapat bahwa surat-surat penggembalaan (pastoral) diantaranya surat Titus tidak berasal dari rasul yang terkenal ini. A. M Hunter berpendapat bahwa surat-surat Pastoral hanya berisi fragmen-fragmen dari tulisan Paulus, dan dalam bentuknya yang sekarang surat-surat Pastoral itu adalah karya seorang murid Paulus ${ }^{5}$ Alasan-alasan yang terpenting yang menentang penulis surat Pastoral adalah Paulus yaitu : (1) karena gaya bahasa dan istilah-istilah yang dipakai lain dari pada yang dipakai dalam surat-surat yang paulinis; (2) masalah-masalah teologis yang dibahas dalam surat pastoral juga berlainnan dengan surat lain; (3) situasi yang dicerminkan dalam isi surat yaitu adanya aperhatian khusus untuk peraturan gereja dan tradisi gereja..

Namun menurut tradisi yang sangat kuat, sebab tradisi tidak boleh dikesampingkan penulis surat Titus adalah rasul Paulus. Argumentasi yang mendukung bahwa Paulus yang menulis surat pastoral adalah perbedaan kata

${ }^{3}$ Leon Mrris, Teologi Perjanjian Baru (Malang: Gandung Mas, 2001), 10.

${ }^{4}$ Ibid, p.27

${ }^{5}$ A.M Hunter, Pengantar Teologi Perjanjian Baru (Jakarta: BPK Gunung Mulia, 2004), 83. 
bergantung pada pokok persoalannya dan gaya bahasanya dapat merupakan soal suasana hati yang tak tetap, waktu yang ada pada penulis dan penerima surat. Dalam hal ini Paulus menulis karena keperluan mendesak yang tibatiba. $^{6}$

Tulisan-tulisan Paulus yang masuk Kanon Alkitab adalah surat-surat yang nyata, yang ditulis kepada orang-orang yang mempunyai masalahmasalah yang nyata. Paulus tidak pernah berusaha menyajikan secara teratur ringkasan teologinya. Semua surat Paulus ditulis pada kesempatankesempatan tertentu saja dan bukan merupakan uraian teologi yang sistematis. Namun dapat dikatakan dengan pasti bahwa Paulus mengungkapkan ide-ide teologi yang penting. ${ }^{7}$ Ide-ide teologi yang dipaparkan Paulus dalam suratnya tersebut patut dipelajari karena menjadi pokok-pokok ajaran Kristen.

Dalam paper ini secara khusus akan dipaparkan pokok-pokok teologi Paulus dalam surat Titus. Meskipun dalam bentuk surat pendek dan bersifat pribadi, namun Paulus menyatakan rumusan kepercayaan Kristen yang paling lengkap dalam seluruh PB dalam surat Titus pada 2 paragrap yaitu :Titus 2:1114 dan Titus 3:4-7.8

Untuk dapat memahami pokok-pokok teologi Paulus dalam Surat Titus ini maka lebih dahulu akan dibahas tentang latar belakang penulisan surat Titus dengan alasan dan tujuan penulisan. Juga perlu dipaparkan secara garis besar isi surat tersebut agar dapat mengerti ide pokok teologi Paulus. Selanjutnya ide-ide teologi tersebut dikelompokkan menurut tema teologinya agar terlihat sistematis. Akhirnya akan dapat disimpulkan ajaran pokok dalam Surat Titus tersebut sehingga dapat diambil tindakan aplikasi pada masa sekarang.

\section{Latar Belakang Surat Titus}

Surat Penggembalaan/Pastoral merupakan dokumen PB yang penting dalam kehidupan Pemimpin Kristen yang mempunyai tanggung jawab di Gereja. ${ }^{9}$ Surat Paulus yang dikelompokkan dalam surat penggembalaan/pastoral adalah I \& II Timotius dan Titus. Istilah pastoral berasal dari bahasa Latin "pastor" yang berarti gembala. Surat

${ }^{6}$ E.M Blaiklock, Surat-Surat Penggembalaan (Malang: Gandum Mas, 1972), 67.

${ }^{7}$ Morris, Teologi Perjanjian Baru, 27.

${ }^{8}$ Merril C. Tenney, Survey Perjanjian Baru (Malang: Gandum Mas, 1992), 419.

${ }^{9} \mathrm{John}$ R.W Stott, The Massage of Timoty and Titus (Leicester: Inter Varsity Press, 1997), 167. 
Paulus kepada Timotius dan Titus ini dinamai surat penggembalaan/pastoral karena berisi petunjuk-petunjuk mengenai bagaimana jemaat Tuhan digembalakan.

Dari data-data yang ada dalam surat pasroral itu, dapatlah disusun kronologis perjalanan Paulus sesudah masa tahanan di Roma. Paulus bersama Timotius berangkat dari Roma untuk mengadakan PI yang sering dikenal dengan istilah perjalanan PI ke-4 pada tahun $62 \mathrm{M}$. Dalam perjalanan misi ini mereka pertama-tama menuju Asia Kecil. Paulus meninggalkan Timotius di Efesus (I Tim. 1:3), kemudian pergi ke Makedonia. Dari Makedonia Paulus menulis surat I Timoius ke Efesus pada tahun 63 M. Setelah itu Paulus kembali ke Asia Kecil bersaama Titus menuju ke Troas (II Tim 4:13), ke Efesus (I Tim 3:14; 4:13), kemudian ke Milite (II Tim 4:20), ke Kreta, dimana ia meninggalkan Titus (Tit. 1:5). Dari Kreta Paulus ke Korintus (II Tim 4:20), ke Nikopolis (Tit.3:12). Di Korintus ini Paulus menulis surat Titus ke Kreta tahun 64M.. Setelah itu Paulus pergi ke Roma dan ia ditangkap dan dipenjarakan. Dipenjara Roma Paulus menulis surat II Timotius ke Efesus tahun 65.

Paulus adalah seorang yang sangat berbakat dalam pelayanan gereja Tuhan. Ia dipanggil secara khusus menjadi Rasul oleh Tuhan Yesus sendiri ketika dalam perjalanan ke Damsyik (KPR 9). Karya pelayanannya sangat luas dan efektif menjadi lebih mudah karena ia akrab dengan dunia Yudasime, Hellenisme dan Romawi. Cara hidupnya sesuai dengan keyakinannya yang mendalam bahwa jalan menuju Allah bukanlah melalui ketaatan kepada hukum Taurat. Dalam semua tulisannya ia senatiasa mengacu pada Kitab Suci Yahudi. Meskipun perhatiannya dicurahkan pada PL dengan senantiasa mengutip PL namun kebanyakan kutipan diambil dari Septuaginta (=Yunani).

Biarpun Paulus adalah seorang Yahudi tulen, tetapi ia kebanyakan bekerja di antara orang-orang bukan Yahudi. Untuk tugas panggilannya ia sudah diperlengkapi ketika tinggal di Tarsus, dimana menjadi tempat ia mendapatkan pendidikan yang baik dan menjadi akrab dengan cara hidup di dunia yang berkebudayaan Helenisme. Paulus juga seorang warga negara Romawi sehingga ia dapat naik banding kepada Kaisar (Kis. 25:11).

Latar belakang yang kompeks dari Paulus sering mempersulit untuk memahami tulisan-tulisannya. Begitu juga dengan gaya bahasa sastra yang dipakai. Karena sebagai pemikir yang ulung, Paulus kadang harus berjuang untuk menemukan bahasa yang tepat yang dapat mengungkapkan hal-hal yang sebelumnya belum pernah dikatakan orang lain.

Titus adalah seorang Yunani dan sahabat karib Paulus. Ia bahkan merupakan penolong Paulus, yang pernah diutus oleh Paulus untuk 
mengunjungi beberapa jemaat supaya ia dapat membantu pelayanan di dalam jemaat-jemaat itu. Dua kali Titus diutus Paulus ke Korintus dengan membawa surat kepada jemaat itu (II Kor. 7:6-13). Oleh Paulus ia ditinggalkan di pulau Kreta supaya Titus dapat menyempurnakan apa yang belum sempurna dalam jemaat. Titus ditugaskan untuk mengatur dan membangun jemaat dengan pengajaran yang sehat karena adanya guru-guru palsu yang menyesatkan jemaat. Ajaran sehat disini berarti pengajaran yang benar. Doktrin yang sehat selalu diharapkan untuk menghasilkan kehidupan yang kudus. Teologi yang sehat bukan hanya dinyatakan melalui pengakuan atau kredo, tetapi melalui kehidupan yang berbuah-buah dalam kehidupan yang kudus. ${ }^{10}$ Selain itu ia juga diperintahkan untuk menetapkan penatua-penatua jemaat seperti yang dilakukan Paulus sebelum Paulus meninggalkan jemaat yang dirintisnya.

Walaupun Paulus sangat mengasihi Titus, namun ia tidak menyatakan isi hatinya kepada Titus sama seperti yang dilakukan kepada Timotius. Rupanya Titus lebih tua dari pada Timotius dan lebih teguh pendiriannya. Paulus menganggap Titus sebagai seorang yang berpendirian serta bijaksana dalam bergaul sehingga diberi tugas mengatur hal-hal yang sulit dalam jemaat. Titus bukanlah seorang uskup yang diangkat dan ditetapkan di Kreta, melainkan Titus merupakan seorang penginjil yang pergi ke berbagai tempat.

Keadaan di Kreta sangat mengecewakan. Pada waktu itu orang Kreta menyebut penyair adalah "nabi". Paulus mengutip sebuah ucapan dari salah seorang penyair itu, seorang Kreta sendiri yang sudah terkenal "Dasar orang Kreta pembohong, seperti binatang buas, pelahap yang malas" (Tit. 1:12). Gereja tidak terorganisasi dan tingkah laku para anggota sangat ceroboh. Hal ini mungkin karena penafsiran yang salah dari pemberitaan Injil kasih karunia yang telah memberi kesan kepada orang-orang Kreta bahwa keselamatan oleh karena iman, tidak ada hubungannya dengan hidup tekun dan saleh. Alasan inilah yang menjadi pokok utama Surat Titus dikirimkan meskipun pendek. Isinya yang terutama meminta orang Kristen untuk melakukan perbuatan baik (6 kali diulang yaitu Tit.1:16; 2:7; 14; 3:1;8;14), meskipun keselamatan tidak dapat diperoleh karena perbuatan yang dilakukan (Tit. 3:5).

Merril C. Tenney dalam bukunya, Survey Perjanjian Baru, memberikan garis besar isi surat Titus berdasarkan keadaan dan tujuan penulisan sebagai berikut: Pokok/tema adalah tentang Ajaran yang Sehat; (I) Ucapan salam: Sumber Ajaran Sehat (1:1-4); (II) Pelaksanaan Ajaran Yang Sehat(1:5-16); (III) Pemberitaan Ajaran yang Sehat (2:1-15) dengan 
pembagian (a) Penerapan (2:1-10), (b) Pengertian (2:11-15); (IV) Pesan-pesan mengenai Ajaran yang Sehat (3:1-11); dan (V) Salam penutup (3:12-15).

Selanjutnya dikomentari bahwa Surat Titus adalah suatu ringkasan yang baik dari pengajaran asas gereja yang sehat waktu gereja dalam tahap pelembagaan. Kata "sehat" menyiratkan bahwa suatu standart asas yang resmi telah ditetapkan, dan harus diikuti oleh kehidupan dan pengajaran yang benar. ${ }^{11}$ Ryrie juga menyatakan bahwa ajaran sehat berarti pengajaran yang benar (2 Tim. 4:3; Tit. 1:9) yang selalu diharapkan untuk menghasilkan kehidupan yang kudus. Ia menekankan bahwa teologi yang sehat bukan hanya dinyatakan melalui pengakuan atau kredo, tetapi melalui kehidupan yang berbuah-buah. ${ }^{12}$

Demikianlah sekilas latar belakang surat Titus yang akan menjadi landasan untuk memaparkan teologi Paulus dan memahami kerangka berpikirnya saat menghadapi persoalan khusus di jemaat tersebut. Gutrie menekankan bahwa sangat penting untuk diperhatikan dalam mempelajari Teologi Perjanjian Baru hal-hal yang mempengaruhi seperti keadaan/suasana di tengah-tengah peritiwa itu yaitu berbagai aliran keagamaan yang hidup di masyarakat. ${ }^{13}$

\section{Pokok-pokok Teologi Paulus dalam Surat Titus}

Pokok-pokok teologi Paulus dalam surat Titus diringkasan secara khusus pada dua bagian yaitu pasal 2:11-14 yang berbunyi:

Karena kasih karunia Allah yang menyelamatkan semua manusia sudah nyata. Ia mendidik kita meninggalkan kefasikan dan keinginan-keinginan duniawi dan supaya kita hidup bijaksana, adil dan beribadah di dalam dunia sekarang ini dengan menantikan penggenapan pengharapan kita yang penuh bahagia dan penyataan kemuliaan Allah yang Mahabesar dan Juruselamat kita Yesus Kristus, yang telah menyerahkan diri-Nya suatu umat, kepunyaan-Nya sendiri, yang rajin berbuat baik. ${ }^{14}$

Serta pasal 3:4-7 yang berkata:

Tetapi ketika nyata kemurahan Allah, Juru Selamat kita, dan kasih-Nya kepada manusia, pada waktu itu Dia telah menyelamatkan kita, bukan

${ }^{11}$ Tenney, Survei Perjanjian Baru, 419.

${ }^{12}$ Ryrie, Teologi Dasar, p.12

${ }^{13}$ Donald Gutrie, Teologi Perjanjian Baru, jil. 1 (Jakarta: BPK Gunung Mulia, 1996), 19.

${ }^{14}$ Titus 2:11-14. 
karena perbuatan baik yang telah kita lakukan, tetapi karena rahmat-Nya oleh pemandian kelahiran kembali dan oleh pembaharuan yang dikerjakan oleh Roh Kudus, yang sudah dilimpahkan-Nya kepada kita oleh Yesus Kristus, Juruselamat kita, supaya kita sebagai orang yang dibenarkan oleh kasih karunia-Nya, berhak menerima hidup yang kekal sesuai dengan pengharapan kita. ${ }^{15}$

Namun tema-tema teologi secara umum juga akan dipaparkan dari bagian-bagian lain dalam surat Titus dari pembukaan sampai penutup surat. Seperti yang dipaparkan oleh Gutrie dalam Teologi PB, pokok-pokok teologi Paulus pada paper ini dikelompokkan mulai ajaran tentang Allah; Kristologi termasuk karya Kristus; Pneumatologi; Kehidupan Kristen; ajaran tentang Jemaat; Eskatologi dan akhirnya tentang etika yang menghubungkan masalah moralitas dengan teologi.

\section{Ajaran tentang Allah}

Paulus sebagai seorang teolog sejati adalah seorang Yahudi yang mempercayai adanya Allah sebagai pribadi yang agung dan mulia, sehingga ia menaruh perhatian yang amat besar kepada Allah. Paulus mempergunakan nama Allah $(\theta \varepsilon \circ \varsigma)$ dengan amat sering dibanding penulis PB lainnya. Hampir $40 \%$ acuan pada Allah dalam PB berasal dari Paulus. Dalam surat Titus yang singkat 11 kali Paulus memakai kata Allah (Tit. 1:1a,1b; 1:2; 1:3; 1:4; 1:7; $1: 16 ; 2: 5 ; 2: 10 ; 2: 11$; dan $2: 13$ ).

Bagi Paulus Allah itu penting, sehingga ia selalu berbicara tentang Allah yang menjadi pusat pikirannya. Paulus mengajarkan bahwa Allah berdaulat atas kehidupan manusia dalam segala aspek, sehingga tidak ada satu bagian pun dari pengalaman manusia yang dianggap tidak ada hubungannya dengan Allah. Penggungkapan keberadaan Allah dan sifat-sifatNya dalam surat Titus yaitu: Allah sebagai pemilik; Allah sebagai Juruselamat dan Allah sebagai Bapa. Dan dihubungkan dengan garis besar isi surat Titus, keberadaan Allah ini merupakan sumber dari ajaran yang sehat.

\section{Allah Sebagai Pemilik}

Paulus menyatakan dirinya pada awal surat Titus ini sebagai hamba

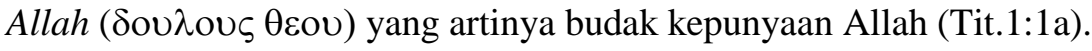


Selanjutnya tugas dari kedudukan Paulus sebagai budak milik Allah adalah untuk memelihara orang-orang pilihan Allah ( $\varepsilon \kappa \lambda \varepsilon \kappa \tau \omega \nu$ $\theta \varepsilon \mathrm{ov})$ yang diartikan orang-orang milik/kepunyaan Allah (Tit. 1:1b). Selanjutnya dalam surat itu salah satu tugas Titus adalah untuk menetapkan para penatua/penilik jemaat. Penatua/penilik jemaat adalah seorang pengatur rumah Allah atau rumah

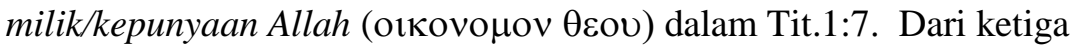
penggunaan kata Allah $(\theta \varepsilon \circ \varsigma)$ dalam kasus genetif milik tersebut dapatlah ditarik kesimpulan bahwa Paulus ingin menjelaskan bahwa Allah adalah yang empunya pelayanan dan orang-orang yang terlibat didalamnya, baik itu pelayan-pelayan (rasul dan penatua/penilik) maupun lembaga atau jemaat yang disebutkan sebagai suatu rumah. Hal ini sangat penting untuk dipahami sebab milik Allah harus dalam jalan kebenaran.

\section{Allah Sebagai Juruselamat}

Meskipun gelar "Juruselamat" umumnya diterapkan kepada Yesus Kristus, namun gelar ini juga digunakan bagi Allah, sesuai dengan tindakan Allah yang menonjol dalam PL. Meskipun jarang disebut, namun karya penyelamatan yang terkandung dalam gelar ini menjiwai PB terutama dalam surat-surat pastoral secara khusus dalam surat Titus. Paulus menyebutkan bahwa Allah adalah Juruselamat sebanyak 4 kali dalam surat Titus yang pendek ini $(1: 3 ; 2: 10,11 ; 3: 4)$. Seluruh teologi dan pengalaman religius Paulus sepenuhnya didasarkan pada apa yang telah dikerjakan Allah di dalam Kristus demi keselamatan manusia. Sesungguhnya, teologi Kristen berpusat pada tema mengenai Allah yang menyelamatkan umat-Nya. ${ }^{16}$

Allah sebagai Juruselamat yang dinyatakan Paulus dalam salam pembuka surat Titus ini merupakan sumber ajaran sehat atau pengetahuan akan kebenaran ( $\varepsilon \pi \imath \gamma v \omega \sigma \iota v \alpha \lambda \varepsilon \theta \varepsilon l \alpha \varsigma)$. Istilah kebenaran biasanya dipakai dalam arti kebaikan etika, sebagaimana yang digunakan orang Yunani. Akan tetapi orang Yahudi memakai istilah tersebut dalam arti status hukum.

Kadang-kadang kebenaran dan keselamatan dikaitkan satu sama lain dalam PL, seperti ketika Allah berfirman,"KeselamatanKU akan tetap untuk selama-lamanya, kebenaranKU tidak pernah akan berakhir" (Yes. 51:6) demikian juga pemazmur ketika menulis, "Tuhan telah memperkenalkan keselamatanNya dan menyatakan kebenaranNya kepada bangsa-bangsa" (Maz. 98:2). Disini perlu menangkap maksud Paulus bahwa jika Allah

${ }^{16}$ Gutrie, Teologi Perjanjian Baru, 62. 
menyelamatkan, Ia menyelamatkan dengan cara yang sesuai dengan kebenaran. ${ }^{17}$ Paulus kadang juga memakai ungkapan ini untuk menyatakan suatu sifat Allah. Allah pada hekekatnya adalah benar dan dapat diandalkan untuk bertindak dalam kebenaran. Akan tetapi secara khusus ungkapan ini berarti suatu keadaan benar yang berasal dari Allah dan yang merupakan anugerah Allah. ${ }^{18}$

Kebenaran sangat penting untuk dilihat sebagai suatu anugerah cuma-

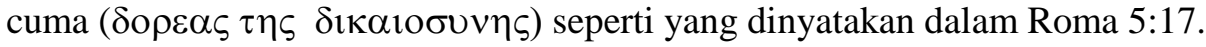
Dalam arti yang biasa, kata itu yakni dalam arti kebaikan etika, kebenaran tidak dapat diberikan seperti juga tidak dapat dirampas. Kebenaran semacam ini harus diperoleh lewat perbuatan etika yang baik Bahwa kebenaran itu suatu anugerah, menunjukkan suatu tindakan Allah memberi orang status "benar". Gagasan bahwa keselamatan adalah oleh anugerah/kasih karunia terdapat di seluruh PB, secara khusus sering dinyatakan oleh Paulus dalam tulisannya.

Tindakan Allah menyelamatkan manusia dalam surat Paulus kepada Titus, dinyatakan secara jelas sebagai tindakan dari pribadi Allah Tritunggal (Tit. 3:4-6). Paulus menyebut oknum Allah Tritunggal secara bersama-sama, tetapi diungkapkan dalam struktur yang jelas. Allah Bapa menyatakan kemurahanNya dan kasihNya kepada manusia ( $\dot{\eta} \chi \rho \eta \sigma \tau o ́ \tau \eta \varsigma ~ \kappa \alpha i ̀ ~ \dot{\eta}$

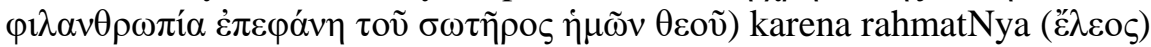
oleh pemandian kelahiran kembali dan oleh pembaharuan yang dikerjakan oleh

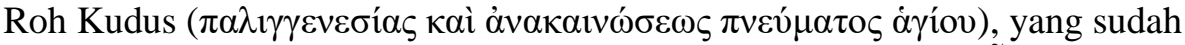
dilimpahkan kepada kita oleh Yesus Kristus, Juruselamat kita (oṽ $\dot{\varepsilon} \xi \dot{\varepsilon} \chi \varepsilon \varepsilon v ~ \varepsilon \dot{\varphi} \varphi$

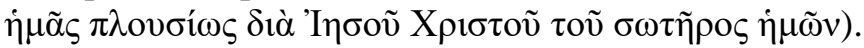

Dua aspek yang berhubungan dengan kasih Allah adalah kasih karunia $(\chi \alpha \rho ı \varsigma)$ dan rahmat ( $\left.\varepsilon^{\prime} \lambda \varepsilon \circ \varsigma\right)$. Kasih karunia Allah merupakan ciri dari kasih Allah yang hakiki yang menunjuk pada kemurahanNya terhadap mereka yang tidak layak menerima kemurahan itu. Jika anugerah/kasih karunia diterapkan pada Allah secara khusus digunakan bagi karya penyelamatan Allah dalam Kristus. Ini merupakan keyakinan dasar sehingga sering dipakai dalam salamsalam pembuka dan penutup/berkat (lihat Tit. 1:4, 3:15).

Anugerah/kasih karunia Allah yang dinyatakan Paulus dalam Surat Titus pasal 2:11-14 dan pasal 3:4-7 menjadi inti berita dari ajaran sehat. Paulus mengungkapkan bahwa kasih karunia Allah adalah kemurahan hati Allah yang tidak pantas diterima oleh orang yang layak dihukum. Istilah ini dalam Titus 3:7 dipakai untuk mengungkapkan sikap Allah yang menyediakan

\footnotetext{
${ }^{17}$ Morris, Teologi Perjanjian Baru, 41.

${ }^{18}$ Ibid., 42.
} 
keselamatan bagi manusia terutama dalam misi Yesus. Kasih karunia Allah merupakan sikap yang Allah perlihatkan, yang bertentangan dengan "karya

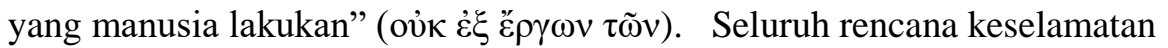
dipandang sebagai penampakan kasih karunia Allah sebagai pilihan Allah yang penuh anugerah.

Dalam perikop Titus 2:11-14, kasih karunia Allah dipaparkan sebagai anugerah Allah yang tak terhingga bagi manusia yang menanggapi kasihNya yang abadi. Paulus menggunakan bentuk kata kerja perfek untuk menyatakan

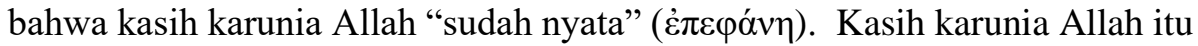
"menyelamatkan" yaitu dengan cara Kristus telah menyerahkan diriNya untuk membebaskan dari segala kejahatan. Kasih karunia Allah itu diberikan bagi semua orang.

Selanjutnya Paulus menyebutkan tujuan dan akibat dari pemberian kasih karunia Allah waktu ini kepada orang percaya. Tujuan kasih karunia Allah adalah bekerja dalam kehidupan orang percaya untuk mendidik/mengajar supaya meninggalkan kefasikan, meninggalkan keinginan-kenginan duniawi dan mendidik untuk hidup bijaksana, adil dan saleh/beribadah di dalam dunia sekarang ini. Juga agar orang percaya dikhususkan/dikuduskan menjadi umat yang rajin berbuat baik. Sedangkan akibat langsung yang dapat dialami saat ini adalah menerima hidup yang kekal. Akibat dimasa depan dari kasih karunia Allah itu adalah pengharapan akan penyataan kemuliaan Allah yang Mahabesar yaitu Juruselamat Yesus Kristus. Ini merupakan penantiaan penggenapan pengharapan yang penuh bahagia. Akibat dari ini jemaat yang mula-mula lebih memikirkan kedatangan Tuhan Yesus kedua kali daripada memikirkan kematian. ${ }^{19}$

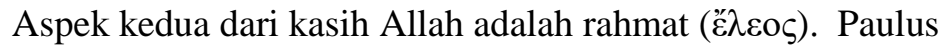
mengungkapkan hal ini dalam Titus 3:4 bahwa rahmat Allah ini sama dengan arti belas kasihan atau kemurahan berhubungan dengan kebenaran dan keadilan. Karena arti dasarnya ialah "belas kasihan" maka mempunyai hubungan yang sangat erat dengan kasih, karena sifatnya yang hakiki adalah memberi kepada orang lain. Dalam pemikiran Yahudi rahmat Allah umumnya dihubungkan dengan ketaatan kepada perjanjian. Doktrin Yahudi dalam naskah-naskah Laut Mati mengajarkan bahwa orang baik menerima upah karena rahmat, sedangkan orang jahat memang sepantasnya menerima hukuman. Dasar pandangan ini ialah walaupun perbuatan-perbuatan baik manusia mempunyai kontribusi dalam keselamatan, tetapi sama sekali tidak 
akan pernah cukup memperoleh keselamatan. Jadi jelas bahwa rahmat Allah mempunyai peran dalam keselamatan.

Paulus kadang-kadang memakai kata seperti, "kebaikan hati" untuk menggambarkan sikap Allah yang murah hati. Hubungan yang erat antara anugerah/ksih karunia Allah dan kemurahan jelas terlihat dalam Efesus 2:7 disitu dikatakan bahwa kekayaan kasih karuniaNya yang melimpah-limpah disamakan dengan kebaikanNya ( $\kappa \lambda \rho \varepsilon \sigma \tau \mathrm{o} \tau \varepsilon \zeta)$ terhadap orang percaya dalam Kristus. Karena itu $\kappa \lambda \rho \varepsilon \sigma \tau 0 \tau \varepsilon \zeta$ hampir sama artinya dengan anugerah/kasih karunia. Paulus dalam Titus 3:4 menyatakan bahwa kemurahan dan kasih Allah, keduanya "nyata" di dalam penyelamatan manusia.

\section{Allah Sebagai Bapa}

Ajaran tentang kebapaan Allah adalah ajaran yang paling khas dalam PB dan khususnya dalam ajaran Yesus. Pada masa itu, orang-orang penyembah berhala beribadah kepada dewa-dewanya dalam suasana ketakutan, tetapi pandangan Kristen tentang kebapaan Allah memberikan unsur kemesraan ke dalam hubungan manusia dengan Allah yang tidak ada bandingnya dalam dunia kafir. Sedangkan dalam PL dan dalam pemikiran orang Yahudi gagasan ini tidak ada. Dalam PL, Allah dianggap Bapa umatNya, dimana dalam pengertiannya sebagai bangsa, bukan sebagai pribadi. Akan tetapi, perlu diperhatikan bahwa gagasan hubungannya dengan suatu kumpulan orang tidak menghilangkan gagasan kebapaan dalam hubungannya secara pribadi. Hal ini justru merupakan persiapan bagi perkembangan gagasan kebapaan allah seara penuh dalam PB.

Perjanjian Baru mengemukakan tiga gagasan mengenai kebapaan Allah. Allah adalah Bapa Yesus, Allah merupakan juga Bapa murid-murid Yesus (Bapa orang-orang percaya) dan ketiga Dia menjadi Bapa dari semua ciptaanNya. Penting untuk diperhatikan bahwa hubungan "bapa-anak" yang bertitik tolak pada Allah hampir seluruhnya ditujukan bagi orang-orang yang percaya. Hubungan ini terjadi karena tindakan penebusan atau penyelamatan dari Allah.

Dalam salam pendahuluan pada semua surat kiriman Paulus, Allah digambarkan sebagai Bapa termasuk surat kepada Titus (Tit.1:4). Hal ini merupakan keyakinan yang mendasari segala sesuatu yang ditulis oleh Paulus dalam surat-suratnya. Lagi pula Paulus sering menampakkan kebapaan Allah dalam pembahasan-pembahasan mengenai doktrin atau yang berkenaan dengan 
kelakuan praktis. Kebapaan Allah ini sungguh berpengaruh dalam teologi PB dibanding dengan gagasan lain tentang Allah. ${ }^{20}$

\section{Ajaran Tentang Yesus Kristus}

Paulus adalah seorang yang mewarisi kebiasaan orang Kristen menyebut Juruselamat dengan istilah "Kristus" sekalipun banyak orang Kristen tidak menyadarinya. Di dalam PB, Paulus menggunakan kata "Kristus" sekitar $70 \%$ yakni 379 kali dari 529 kali penggunaan gelar itu dalam PB. Ini menjelaskan bahwa Paulus berbeda dengan penilis PB lainnya dalam menggunakan gelar ini. Akan tetapi sangat istimewa Paulus menggunakan kata ini dalam surat Titus yang pendek sebanyak 4 kali saja (Tit. 1:1, 4; 2:13 dan Tit. 3:6).

Kata "Kristus" adalah trasliterasi sebuah kata Yunani yang berarti "diurapi" sama seperti "Mesias" adalah transliterasi kata Ibrani dengan arti yang sama. Dalam PL orang yang diurapi ada tiga kelompok yaitu raja, imam dan nabi. Dalam peristiwa pengurapan menandakan bahwa orang yang bersangkutan secara resmi dikhususkan bagi pelayanan Allah. Namun lambat laun muncullah gagasan bahwa suatu hari akan tampil tidak hanya seorang yang diurapi melainkan orang tertentu yang diurapi, orang yang melaksanakan kehendak Allah secara istimewa. Ungkapan "Mesias" sendiri jarang muncul dalam PL, tetapi gagasannya sering dijumpai, pada saat-saat tertentu dalam sejarah Israel, lebih-lebih dalam jaman PB sehingga meluaslah pengharapan orang akan kedatangan Mesias.

Paulus sering juga memakai nama manusiawi yaitu "Yesus" secara menarik. Nama itu tidak banyak dipakai untuk Yesus selama hidupNya di dunia ini. Akan tetapi, orang-orang Kristen yang mula-mula mengakui bahwa Yesus adalah Orang pilihan Allah tersebut, sebagaimana tampak dengan jelas dari seringnya Paulus memakai ungkapan itu. Meskipun Paulus sedikit sekali berbicara mengenai peristiwa-peristiwa dalam kehidupan Yesus di dunia, mungkin karena ia mau mengungkapkan kebenaran bahwa kemanusiaan Yesus itu nyata dan penting. Ada pertanyaan muncul apakah Paulus memandang kata itu sebagai suatu gelar "Sang Mesias" atau sebagai nama diri. Ada pendapat bahwa seringnya Paulus memakai urutan kata "Kristus Yesus" menunjukkan bahwa ia memandangnya sebagai suatu gelar. Namun ada argumentasi yang 
meyakinkan bahwa dalam dunia non Yahudi gelar "Kristus" tidak mempunyai arti sama sekali.

Meskipun demikian, jikalau Paulus menggabungkan kedua nama itu, seperti yang dibuatnya, dia lebih suka dengan urutan "Kristus Yesus" (83 kali) daripada "Yesus Kristus" (26 kali). Akan tetapi dalam surat Titus, Paulus menggunakan dua nama itu dengan urutan "Yesus Kristus" 3 kali (Tit. 1:1, 2:13 dan 3:6) dan urutan "Kristus Yesus" satu kali (Tit.1:4).

Ada hal yang sangat menarik dalam Surat Titus ini, dimana Paulus menyebutkan istilah lain perihal Yesus Kristus yaitu Yesus sebagai Juruselamat (Tit. 1:4; 2:13). Hal ini barangkali tidak sering banyak orang sangka. Tetapi gelar ini jelas gelar yang amat tinggi, sebab ada ungkapan "Allah Juruselamat kita" (Tit. 1:3; 2:10; 3:4). Memang ada alasan yang kuat untuk menegaskan bahwa dalam pandangan PB, gagasan Yesus sebagai Anak Allah mendapat tempat yang penting. Namun lebih mengagumkan lagi bahwa Yesus disebut Allah, khususnya jika mengingat monotheisme orang Yahudi yang demikian kuat.

Paulus dengan macam-macam cara menunjukkan aspek Yesus Kristus yang lebih dari seorang manusia. Kebiasaan Paulus salah satunya adalah menggolongkan Juruselamatnya itu sejajar dengan Allah, mengacu kepada Kristus seperti kepada Allah Bapa dalam mengawali surat-suratnya dengan salam "Kasih karunia dan damai sejahtera dari Allah Bapa dan Kristus Yesus, Juruselamat kita menyertai kamu." (Tit. 1:4)

Juga dalam Titus 2:13 Paulus menghubungkan Allah dengan Yesus meskipun ada kemungkinan pengertian yang berbeda. Dalam bahasa Yunani

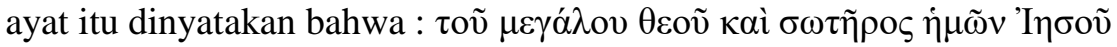
X Mahabesar dan Juruselamat kita", tetapi ayat ini mungkin dapat diterjemahkan 'dari Allah yang besar dan Juruselamat kita Yesus Kristus'. Namun sekali lagi keterangan tata bahasa lebih mendukung terjemahan yang mengatakan Yesus sebagai Allah. Karena seandainya Paulus ingin membedakan antara 'Allah' dan 'Yesus', maka ia akan memakai kata sandang di depan kata theos dan di depan kata Yesus juga. ${ }^{21}$ Seperti yang sudah dibahas dibagian sebelumnya tentang keterlibatan Allah Tritunggal dalam keselamatan dimana Paulus menyebut oknumTritunggal secara bersama-sama.

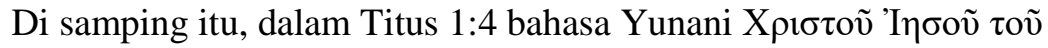
$\sigma \omega \tau \tilde{\eta} \rho \varsigma \dot{\eta} \mu \tilde{\omega} v$ mendukung terjemahan "Kristus Yesus Juruselamat kita", sehingga wajar untuk berpendapat bahwa ungkapan ini dipakai dalam Titus 
2:13 juga. Sebab hal ini tidak ada alasan-alasan yang cukup untuk menyangkal bahwa dalam konteks ini Yesus Kristus digambarkan sebagai Allah yang menyelamatkan. Dalam Titus 2:14 dinyatakan dengan jelas apa tentang karya Yesus Kristus dalam keselamatan yaitu membebaskan/menebus orang percaya dari segala kejahatan dengan menyerahkan diriNya. Kata menebus yang dipakai merupakan ciri khas Paulus yaitu lutrou. Kata ini bermakna bahwa pemberian diri Kristus ini sebagai harga tebusan dan keadaan asal manusia yang ditebus yaitu lingkungan kejahatan.

\section{Ajaran Roh Kudus}

Peranan Roh Kudus dinyatakan di dalam alam semesta terlihat mulai dari riwayat penciptaan dimana Roh Kudus melayang di atas permukaan air sehingga menghasilkan keteraturan pada keadaan yang belum terbentuk (Kej. 1:2). Lalu peran Roh Kudus berkesinambungan sebagai sumber kehidupan manusia (Kej. 6:3). Selanjutnya dipantulkan pelayanan Roh Kudus dalam rangka pemeliharaan manusia (Mzm. 104:29-30) dan pemeliharaan ciptaan (Yes. 40:7). Menyangkut dengan kehidupan manusia, Roh Kudus mengaruniakan ketrampilan akal budi/seni (Kel. 35:30) yang mempunyai arti penting bagi pembahasan karunia-karunia Roh Kudus dalam jemaat dalam masa PB.

Dalam surat Titus yang pendek, Paulus menyinggung sedikit akan peran Roh Kudus dalam kehidupan orang percaya. Hanya satu kali saja penggunaan Roh Kudus dalam surat Titus oleh Paulus yaitu dalam Tit. 3:5 dengan istilah bahasa Yunani $\pi v \varepsilon v ́ \mu \alpha \tau o \varsigma$ ójíov. Namun demikian menurut Paulus, karya Roh Kudus memainkan peran yang hakiki dalam proses kelahiran kembali mirip dengan pengajaran Yesus kepada Nikidemus dalam Yoh. 3:5. Paulus membangun teologinya tentang Roh Kudus atas dasar bahwa semua orang percaya memiliki Roh Kudus; tak seorangpun dapat memberi sambutan kepada himbauan Kristus tanpa digiatkan dan didiami Roh Kudus. Bahkan Allah menyelamatkan orang percaya oleh pemandian kelahiran kembali dan pembaharuan yang dikerjakan oleh Roh Kudus. (Tit. 3:5).

Penting untuk diingat dan dipahami dalam hal ini bahwa terjemahan pemandian dalam ayat 5 tersebut bukan berarti baptisan. Alasan untuk hal ini karena ada ajaran yang menyesatkan yaitu bahwa "baptisan adalah kuasa untuk menyelamatkan seseorang. Kuasa pembaptisan, pekerjaannya, hasilnya, buahnya dan tujuannya ialah untuk menyelamatkan seseorang." Ajaran tentang orang yang dibaptiskan itu telah diselamatkan sangat bertentangan dengan 
ajaran sehat yang dinyatakan Allah yaitu bahwa keselamatan itu merupakan anugerah Allah oleh pertobatan serta dengan beriman kepada Yesus Kristus. Roh Kuduslah yang melahirkan kembali berdasar iman dan kepercayaan kepada Yesus Kristus. Pembaptisan hanyalah suatu tanda bagi orang-orang bahwa orang-orang yang dibaptis itu telah percaya kepada Yesus dan telah bertobat serta telah dilahirkan kembali.

Kata 'pemandian' yang diterjemahkan dalam ayat ini sebenarnya memakai kata bahasa Yunani loutrou yang tepat diterjemahkan pembasuhan. Lain lagi J.B Philips menterjemahkan ayat tersebut demikian: "melainkan oleh kuasa penyucian kelahiran baru dan pembaharuan oleh Roh Kudus." Dua bagian dalam kalimat itu membicarakan satu pekerjaan dan satu tujuan, yaitu pembaharuan yang terjadi atas orang percaya oleh pekerjaan Roh Kudus. ${ }^{22}$

Sebenarnya yang dibicarakan dalam ayat tersebut adalah pekerjaan Roh Kudus di dalam hati manusia. Ini bukan tanda-tanda mujizat dari luar, melainkan pekerjaan di dalam batin. Ayat ini tidak ada hubugannya dengan pembaptisan, melainkan tentang pekerjaan yang berlangsung di dalam. Pembaptisan hanyalah sebagai tanda bahwa pekerjaan di dalam batin sudah selesai.

Selanjutnya Paulus agaknya mengingatkan Titus tentang Roh Kudus yang telah dicurahkan pada hari Pentakosta seperti yang dijanjikan Allah dalam Yoel 2:28, bahwa Ia akan mencurahkan RohNya ke atas segala bangsa. Dalam ayat 6 Paulus menyatakan bahwa Roh Kudus dicurahkan dengan berkelimpahan kepada orang percaya. Maksud dari pencurahan Roh Kudus dengan limpahnya ini supaya orang percaya sebagai orang yang dibenarkan oleh kasih karuniaNya, berhak menerima hidup yang kekal sesuai dengan pengharapan (ayat 7). Bagian ini merupakan pesan penting mengenai ajaran yang sehat kepada Titus dimana Paulus menekankan bahwa perkataan yang baru saja disamapaikan adalah benar (ayat 8) dan menjadi dorongan yang meyakinkan untukmelakukan perkerjaan yang baik

\section{Ajaran tentang Kehidupan Kristen}

Iman merupakan pusat pengalaman Paulus maupun teologinya yang digambaran dengan istilah pistis . Kata pistis dalam surat Titus dapat berarti kesetiaan, benar, sehat dan patut diterima (Tit.1:1, 4, 6, 9, 13; 2:1, 3:8, 15). Paulus telah menjadikan kata 'iman' sebagai satu istilah penting dalam

\footnotetext{
${ }^{22}$ Brill, Tafsiran Titus, 121.
} 
kosakata Kristen. Ia terus mempergunakannya sebanyak 142 kali baik dalam bentuk kata kerja, benda maupun kata sifat. Paulus memakai kata ini sedemikian rupa, supaya para pembacanya tidak akan ragu-ragu bahwa iman itu fundamental bagi orang Kristen. ${ }^{23}$ Paulus menggunakan istilah iman dengan beberapa aspek hidup orang percaya. Iman pada hakekatnya berarti menerima amanat Allah yaitu tanggapan manusia kepada pemberitaan Injil. Pembenaran hanya dapat dicapai melalui iman. Iman mencakup suatu proses yang berkesinambungan. Iman itu berkembang dan dinamis. Iman berarti penyerahan yang penuh kepada cara hidup Kristen. Dan secara khusus Paulus menggunakan pengertian iman dalam surat Titus untuk menunjukkan kepercayaan Kristen seluruhnya (Tit. 1:13).

\section{Ajaran tentang Jemaat}

Meskipun kata jemaat (ekklesia) tidak terdapat dalam surat Titus yang dikirimkan Paulus, namun ada hal khusus perihal kehidupan jemaat yang disinggung yaitu tentang pemimpin-pemimpin jemaat. Memang, jika dalam pembahasan tentang jemaat dimengerti dari penggunaan istilah ekklesia saja, maka ada keterkejutan karena istilah ini jarang terdapat dan bahkan hanya muncul dalam satu kitab Injil saja (Mat. 16:18; 18:17-18). Sebenarnya Paulus memakai beberapa kiasan baik sering dikanal maupun yang kurang terkenal untuk memahami pengertian tentang jemaat. Umumnya Paulus memandang pengertian jemaat menurut dua cara utama yaitu perhimpunan orang-orang percaya dalam suatu daerah tertentu/lokal dan juga perhimpunan orang-orang percaya secara universal.

Kiasan yang dipakai Paulus untuk memahami jemaat dalam surat Titus ada dua yang terlihat yaitu jemaat sebagai rumah Allah dan jemaat sebagai umat Allah. Kedua kiasan yang digunakan Paulus ini tidak secara jelas dipaparkan secara khusus, tetapi ada makna tersirat yang dalam seperti yang di sampaikan dalam surat Paulus kepada jemaat lokal yang perlu penekananya tentang hakekat sebuah jemaat seperti surat Efesus maupun Korintus. 


\section{Jemaat sebagai Rumah Allah}

Istilah yang disebutkan dalam surat Titus tentang keberadaan jemaat sebagai rumah Allah terdapat dalam Titus 1:7 ' $\theta$ \&oṽ oíkovónov.' Dalam menyebut istilah ini sebenarnya ia sedang membahas tentang para penatua yang menjadi penilik jemaat dimana ditetapkan untuk mengurus/mengatur jemaat sebagai rumah Allah. Paulus pada awalnya mungkin memikirkan gagasan mengenai jemaat adalah rumah Allah dengan menggembangkan ide gagasan yang dinyatakan Yesus dalam Matius 16:18 "Di atas batu karang ini Aku akan mendirikan jemaatKu". Selanjutnya Paulus memandang keseluruhan orang-orang percaya pada suatu daerah sebagai tempat kediaman Allah, tetapi hal ini juga berarti bahwa setiap orang Kristen adalah rumah Allah (I Kor. 3:16; 6:19). Gagasan ini diambil dari gambaran yang diberikan dalam PL mengenai tempat kediaman Allah di dalam ruang maha kudus dalam Bait Allah yang paling dalam. Pada zaman dahulu Allah tinggal di antara umatNya Israel. Gagasan tentang rumah Allah ini betul-betul menjadi kiasan dan karena itu bersifat rohani.

Selanjutnya disinggung juga peran para pemimpin jemaat dalam surat Titus ini. Gagasan yang umum tentang jemaat sebagi tubuh Kristus dan Kristus sebagai kepala yang berfungsi memegang otritas. Oleh karena itu pejabat-pejabat gereja dipandang sebagai orang-orang yang melaksanakan peran mereka di bawah pimpinan Kepala. Istilah yang dipakai untuk pemimpin jemaat adalah tua-tua (presbuterous, Tit. 1:5) dan penilik jemaat (episkopous, Tit. 1:7). Para pemimpin jemat ini bertugas untuk menjalankan peran khusus mengatur jemaat didalamnya mengajar, memelihara dan menjaga orang-orang percaya dari orang-orang penyesat.

Untuk dapat menjalankan perannya dengan baik maka ada kriteria khusus bagi para memimpin jemaat itu. Pemimpin jemaat haruslah menunjukkan keteladanan dan pandai mengajar agar dapat berfungsi mengatur (Tit 2:1-3). Pemimpin jemaat juga harus dapat mendisiplin orang-orang yang berbuat dan bersikap berlawanan dengan tujuan jamaat yang benar, hal ini berhubungan dengan ajaran sesat (Tit. 3:10-11). Dan ternyata perempuan juga disinggung dalam peranannya turut mengatur jemaat dengan mengajar anakanak dan perempuan lainnnya (Tit. 2:3-4) 


\section{Jemaat sebagai Umat Allah yang Sejati}

Gagasan jemaat sebagai umat Allah yang khusus dalam Titus 2:14 adalah gagasan yang biasa karena sering dipakai dalam PL mengenai bangsa Israel yang dipilih menjadi umatNya untuk menjadi bangsa yang kudus. Bangsa Israel dipandang dari sudut teokrasi, dan merupakan suatu umat yang dipilih oleh Allah dan yang dipelihara oleh Allah. Identitasnya senantiasa dipertahankan oleh asal mulanya dalam pilihan ilahi dan tidak pernah oleh usahanya sendiri. Sudah sewajarnya jika Paulus dengan latar belakang kehidupannya sebagai orang Israel tulen, akan memandang jemaat sebagai umat Allah yang khusus/orang-orang pilihan Allah juga untuk hidup kudus (Titus $1: 1 ; 2: 14$ ).

Umat Allah dalam PB ialah perhimpunan orang-orang yang diketahui khusus sebagai orang percaya kepada Tuhan Yesus. Pengertian tentang umat Allah ini telah tergeser dari bangsa yang diperintah Allah menuju perhimpunan orang-orang yang beriman, dan dengan demikian ruang lungkupnya diperluas (bersifat universal), dan keanggotaanya menjadi lebih jelas (yaitu berdasar iman kepada Tuhan Yesus Kristus). Paulus menerapkan gagasan pemilihan kepada orang-orang yang sudah masuk menjadi umat Allah. Jadi jemaat sebagai umat Allah adalah orang-orang yang dipilih Allah untuk menggenapi maksud Allah.

\section{Ajaran tentang Eskatologi}

Paulus menaruh perhatian sangat besar kepada penggenapan segala sesuatu, dan ia dengan cara tertentu menyinggung soal akhir zaman ini dalam surat-suratnya. Minat kepada hal-hal eskatologis ini memang tidak asing di antara orang Yahudi. Namun apa yang khas bagi Paulus adalah pahamnya mengenai peranan Kristus di akhir zaman. Eskatologi dalam pengertian yang amat menegsankan adalah 'hal-hal pertama' dari orang Kristen, dan bukan 'hal-hal terakhir'. ${ }^{24}$

Dalam pembahasan tentang hal ini penulis sangat setuju dengan pendapat Donald Gutrie yaitu bahwa yang dimaksud dengan ajaran tentang eskatologi secara khusus berbicara tentang masa yang akan datang atau jaman akhir. Alasannya karena istilah eskatologi berasal dari bahasa Yunani eskathos yang berarti "terakhir". Bahasan biasanya mengenai akhir jaman adalah

\footnotetext{
${ }^{24}$ Morris, Teologi Perjanjian Baru, 116.
} 
tentang kedatangan Kristus kedua kali, kebangkitan dan kekekalan. Namun secara khusus dalam pokok ajaran Paulus di Surat Titus akan dibahas tentang kedatangan Kristus kedua kali.

Istilah yang biasa dipakai untuk kedatangan Kristus dalam PB adalah parousia, apokalupsis, epifanea dan hari Tuhan. Istilah parousia biasanya menunjukkan kedatangan atau kehadiran seseorang. Tapi berhubungan dengan Kristus parousia dipakai khusus tentang peristiwa puncak yang akan terjadi nanti waktu Kristus datang kembali pada hari-hari terakhir. Sedangkan kata apukalupsis yang berarti 'penyataan' mengandung pengertian tersingkapnya beberapa kebenaran surgawi yang sampai saat itu masih tersembunyi. Istilah yang searti dengan apukalupsis adalah epifanea yang berarti perwujudan yang mulia.

Paulus dalam surat Titus memakai istilah epifanea untuk menunjukkan tentang kedatangan Yesus Kristus yang menyatakan diriNya dalam perwujudan yang mulia (Tit. 2:13). Jika pada kedatangan Kristus yang pertama ke dunia Ia datang dengan kerendahan dan kehinaan dengan maksud untuk memberikan keselamatan, maka pada kedatanganNya yang kedua, Ia akan datang dalam kemuliaan untuk memberikan kehidupan yang kekal. Dalam menggunakan istilah dalam konteks ini Paulus sedang membahas tentang kasih karunia Allah yang dinyatakan kepada orang percaya (Tit. 2:11). Kasih karunia Allah ini menjadi sumber dari ajaran sehat bagi orang percaya. Sumber ajaran sehat yang disebut disini berhubugan dengan apa yang menjadi pengharapan yang penuh bahagia. Pengharapan ini dinanti penggenapannya karena sifat dari Allah yang tidak berdusta sejak mulanya (Tit. 1:2). Memang Paulus dalam isi bagian pokok surat Titus menunjukkan bahwa kedatangan Kristus merupakan mulainya suatu keadaan bahagia yang final. Wujud dari kebahagiaan yang menjadi pengharapan orang percaya adalah hak memperoleh hidup yang kekal (Tit. 3:7). Pengharapan yang demikian merupakan kekuatan, serta akan menolong orang percaya daalam menghadapi kesulitan dan segala kesusahan sehari-hari.

Paulus dalam menyatakan kebenaran ini selanjutnya memberikan pesan-pesan kepada orang percaya karena keyakinan ini berusaha sungguhsungguh untuk melakukan perbuatan yang baik agar berguna bagi manusia. (Tit.3:8). Bagian selanjutnya ini merupakan penerapan praktis kepada Titus dan jemaat yang dilayaninya. Sudah menjadi pola Paulus dalam surat-suratnya bahwa setelah memberikan suatu pengajaran dilanjutkan dengan aplikasi praktis. 


\section{Ajaran tentang Etika}

Teologia PB tidaklah lengkap tanpa mempertimbangkan ajaran etika PB. Seperti dalam pendahuluan paper ini bahwa pengertian teologi yang dinyatakan oleh Morris merupakan kiat orang kristen untuk menyajikan secara teratur pemahaman mengenai Allah dan penyataanNya dalam Kristus dengan tujuan memberi makna bagi orang yang menyembahNya. Jadi setelah memahami kebenaran mengenai Allah dalam Kristus maka perlu bentuk norma hidup atau etika dalam tingkah laku.

Paulus memberi perhatian khusus pada manusia baru dalam Kristus. Penjelasannya mengenai anugerah Allah melibatkan perubahan dalam etika pribadi, karena manusia baru itu mutlak harus mengembangkan tata nilai baru yang serasi dengan kedudukannya yang baru. Ciri khas surat-surat Paulus yaitu bahwa ulasan teologi/doktrin dilengkapi dengan bahasan etis.

Prinsip-prinsip etika Paulus yang dinyatakan dalam surat-suratnya antara lain sifat tidak sistematis, tidak bersifat asketis, tidak bersifat legalistis dan pada dasarnya dibimbing oleh Roh Kudus. Sedangkan unsur-unsur yang menjadi pendorong etika Paulus adalah kasih; kuasa keteladanan, citra yang patut; akal budi dan pembaharuan; dan harapan akan kedatangan Kristus .

Ajaran etika dalam surat Titus memakai istilah secara khusus berhubungan dengan kebajikan. Dalam Titus 1:7-8 dinyatakan tentang sikap etis yang merupakan syarat bagi penilik jemaat yaitu tidak bercacat, tidak angkuh, bukan pemberang, bukan pemabuk, bukan pemarah, tidak serakah,melainkan suka memberi tumpangan, suka akan yang baik, bijaksana, adil, saleh, dapat menguasai diri dan berpegang kepada perkataan yang benar sesuai dengan ajaran yang sehat. Dalam Titus 2:2-10 adalah daftar tingkah laku anggota-anggota kelompok jemaat baik bagi laki-laki dan perempuanperempuan tua; orang-orang muda dan juga bagi hamba-hamba.

Penekanannya ialah kesungguhan dan kesederhanaan tetapi juga iman dan kasih yang sehat. Bagian ini adalah pemberitaan akan penerapan dari ajaran yang sehat.

\section{Kesimpulan}

Meskipun singkat dan agak mendesak surat Paulus kepada Titus, tetapi isinya penuh dengan ajaran-ajaran pokok Kristen yang sangat fundamental bagi kehidupan orang percaya. Tema pokok teologi Paulus dalam surat Titus adalah tentang ajaran yang sehat guna mendorong melakukan 
perbuatan yang baik. Ajaran yang sehat itu bersumber pada Allah yang telah menyatakan kasih karuniaNya. Allah itu dinyatakan sebagai pemilik, juruselamat dan bapa. Kasih karunia Allah itu telah menyelamatkan orang percaya oleh karena Kristus telah menyerahkan diriNya, kelahiran kembali dan pembaharuan yang dilakukan Roh Kudus. Kasih karunia Allah memberikan pengharapan akan kemuliaan yang dinyatakan pada kedatangan Kristus ke dua kali . Kasih karunia Allah mendidik dan mengajar untuk meninggalkan kefasikan dan keinginan duniawi dengan tujuan supaya orang percaya hidup melakukan perbuatan baik.

Akhirnya aplikasi yang dapat diambil dari hal yang dibahas di sini adalah pentingnya pemahaman yang mantap dan teguh akan ajaran yang benar agar tidak mudah disesatkan dengan pengaruh-pengaruh buruk dari lingkungan dunia di mana orang percaya tinggal, baik dari cara berpikir, maupun bertindak. Juga perlunya menerapkan secara praktis kebenaran ajaran sehat itu di dalam jemaat dengan bertingkah laku yang baik melalui keteladan hidup Kristus yang menjadi Juruselamat sambil terus berpegang pada pengharapan akan penyataan kemuliaan Allah yang Mahabesar. 


\section{Bibliografi}

Blaiklock, E.M. Surat-Surat Penggembalaan. Malang: Gandum Mas, 1972. Brill, J.Weley. Tafsiran Surat Timotius dan Titus. Bandung: Yayasan Kalam Hidup, tt.

Everett F. Harrison, Geoffey W. Bromily dan Carl F.H. Henry (ed), Bakser's Dictionary of Theology (Grand Rapids, 1960

Gutrie, Donald. Teologi PB 1. Jakarta: BPK Gunung Mulia, 1996.

Hunter, A. M. Pengantar Teologi Perjanjian Baru. Jakarta: BPK Gunung Mulia, 2004.

Morris, Leon. Teologi Perjanjian Baru. Malang: Gandung Mas, 2001. Ryrie, Charles C. Teologi Dasar I. Yogyakarta: Yayasan Andi, 1991.

Stott, John R.W. The Massage of Timoty and Titus. England: Inter Varsity Press, 1997.

Tenney, Merril C. Survey Perjanjian Baru. Malang: Gandum Mas, 1992. 